\title{
Quality characteristics of steamed rice cake with Schisandra chinensis powder or extract added prior to storage
}

\author{
Dae-Hyun Kim ${ }^{1}$, Jeong-Seok Cho ${ }^{2}$, Jung-Hoon Park $^{2}$, Jae-Hwan Kim ${ }^{3}$, \\ Kwang-Deog Moon ${ }^{2,4 *}$ \\ ${ }^{1}$ Korea Food Research Institute, Seongnam 13539, Korea \\ ${ }^{2}$ Department of Food Science and Technology, Kyungpook National University, Daegu 41556, Korea \\ ${ }^{3}$ Jisan Food System Co., Ltd., Busan 46332, Korea \\ ${ }^{4}$ Food and Bio-Industry Research Institute, Kyungpook National University, Daegu 41566, Korea
}

\section{오미자 분말 및 추출물 첨가 설기떡의 저장 중 품질특성}

\author{
김대현 ${ }^{1} \cdot$ 조정석 ${ }^{2} \cdot$ 박정훈 $^{2} \cdot$ 김재환 $^{3} \cdot$ 문광덕 $^{2,4 *}$ \\ ${ }^{1}$ 한국식품연구원, ${ }^{2}$ 경북대학교 식품공학부, ${ }^{3}$ (주)지산푸드시스템, ${ }^{4}$ 경북대학교 식품생물산업연구소
}

\begin{abstract}
The purpose of this study was to improve the quality of the steamed rice cakes added with powder and extract of Schisandra chinensis (SC). Steamed rice cakes were prepared by adding SC using $1 \%$ hot-air dried SC powder (DP), hot-air dried SC extract (DE), freeze dried SC powder (FP) and, frozen SC extract (FE). After packaging with nylon/polyethylene films, the cakes were stored at $25^{\circ} \mathrm{C}$ for 5 days. The FE-treated steamed rice cake had the lowest $\mathrm{pH}$ value. The $\mathrm{L}^{*}$ value of the control cakes was highest immediately after processing and decreased during storage. The a* values of FP- and FE-treated steamed rice cakes were higher than those of DP- and DE-treated cakes. The $b^{*}$ values of DP- and DE-treated steamed rice cakes were higher than those of FP- and FE-treated cakes. Total phenolic contents of DP and DE were lower than those of FP and FE. Anthocyanin contents of DPand DE-treated steamed rice cakes were lower than those of FP- and FE-treated cakes. Schisandrin contents of DP- and FP-treated steamed rice cakes were lower than those of DE- and FE-treated cakes. Feric reducing antioxidant power assays revealed that DP and DE had lower antioxidant powers than those of FP and FE. The results of this study indicate that, among the treatments methods used, the steamed rice cake treated with FE had the highest functional component and antioxidant activity levels.
\end{abstract}

Key words : Schisandra chinensis, steamed rice cake, anthocyanin, schisandrin, quality properties

\section{서 론}

현대사회는 경제성장과 국민소득의 증대로 건강과 장수 에 대한 관심이 높아지고, 고급화 및 간편화를 지향하는 경향이 나타나면서 기능성이 더해진 건강 기능성 식품에

*Corresponding author. E-mail : kdmoon@knu.ac.kr Phone : 82-53-950-5773, Fax : 82-53-950-6772

Received 15 July 2016; Revised 30 October 2016; Accepted 9 November 2016.

Copyright (c) The Korean Society of Food Preservation. All rights reserved.
대한 소비자의 욕구가 높아지고 있다. 단순히 영양소를 공 급하는 식사패턴에서 항산화 효과와 같은 기능성 성분을 함유한 건강식을 선호하는 추세로 변화하고 있다. 더불어 각종 부작용을 유발하는 합성 식·의약품에 비해 생리활성 이 우수한 천연식품을 첨가하여 건강식품을 개발하려는 연구가 활발히 진행되고 있다(1).

오미자는 생리활성이 우수한 천연식품으로서 목련과에 속한 Schisandra chinensis의 성숙한 열매를 수확한 것으로 단맛, 신맛, 매운맛, 쓴맛, 짠맛을 가지며 항산화 활성이 강하고(2), 리그난 함량(3)과 페놀 함량(4)이 높으며, 항균작 용(5), 간암 세포 증식 억제 효과(6), 고혈당 조절과 고지질 
함량 감소 효과(7), 알코올 분해능(8) 등의 다양한 생리활성 을 나타낸다고 보고되고 있다. 오미자는 수분함량이 $80 \%$ 이상으로 많으며, 조직이 연하여 생과 상태로 저장이 어려 워 대부분 열풍건조기에서 $60^{\circ} \mathrm{C}$ 이하로 건조하여 건과상태 로 창고에 보관하거나, 냉동 상태로 보관하여 유통하고 있 다(9). 이로 인하여 건조 및 동결 오미자 등 다양한 처리 방법을 통한 오미자를 비교분석 하는 연구가 지속되고 있 다. 오미자를 이용한 건강식품을 개발하기 위한 연구들은 오미자를 첨가한 정과(10), 식빵(11), 두부(12) 등이 있다.

오늘날 식생활의 서구화로 다양한 음식이 소개되고 있으 며, 소비자의 기호를 고려한 각종 즉석 편의 식품과 가공식 품이 개발되고 있다. 또한, 매년 쌀 생산량과 수입량은 증가 하고 있는데 비해 1 인당 쌀 소비량은 줄어들고 있으며, 서구 식의 '빵 중심 식사'면 중심 식사’의 증가로 알레르기 환자 와 비만 환자가 늘고 있는 실정이다(13). 그러나, 떡은 우리 고유의 전통식품일 뿐만 아니라 밀을 주원료 이용한 빵류에 비해 건강에 기여하는 측면이 높다. 또 다양한 가공을 통한 떡의 생산량이 점차 증대되고 있어 쌀의 소비를 촉진할 수 있다는 점에서 현대인의 기호와 식성을 고려한 가공식품 을 지속해서 개발할 필요가 있다(14). 설기떡은 쌀가루로 만든 백설기가 기본을 이루며 그 밖에도 쌀가루에 품질향상 및 부가가치를 향상할 수 있는 방안으로 기능성 소재를 설기떡에 첨가하는 연구들이 지속되고 있다. 다양한 재료 를 첨가한 설기떡의 선행연구로는 화피추출물(15), 흑마늘 추출물(16), 비트잎 가루를 첨가한 설기떡(17)등 다양한 천 연식품을 부재료로 이용하여 만든 떡이 보고되고 있다.

본 연구에서는 동결 및 열풍건조 오미자의 추출물 및 분말을 첨가한 설기떡의 저장기간 중 품질특성, 기능성 성 분의 변화 및 항산화 활성을 비교 검토하여 고품질의 오미 자 설기떡의 최적 가공 방법을 찾고자 하였다.

\section{재료 및 방법}

\section{실험 재료}

본 실험에 사용한 오미자는 2014년도에 경상북도 문경시 에서 수확한 오미자와 이를 $60^{\circ} \mathrm{C}$ 의 열풍을 이용하여 3 일 동안 건조한 오미자로 알맹이가 균일 한 것을 구매하여 사용하였다. 백설기 제조에 필요한 멥쌀은 2014년 충북 예 산에서 생산된 것을 사용하였으며, 백설탕과 소금은 제일 제 ᄃㅏㅇ(CJ Co., Ltd., Seoul, Korea)제품을 구입하여 사용하였 다.

\section{오미자 전처리 및 설기떡의 제조}

본 실험에 사용한 동결건조 오미자 분말은 오미자를 동 결건조기(Clean Vac8, Biotron Inc., Pucheon, Korea)로 건조 하여 분쇄기(NSG-1002SS, Hanil Inc., Seoul, Korea)로 분쇄
후 $20 \mathrm{mesh}$ 체에 걸러 사용하였다. 열풍건조 오미자 분말은 분쇄기로 분쇄 한 후 $20 \mathrm{mesh}$ 체에 걸러 사용하였다. 동결 오미자 및 열풍건조 오미자의 추출물은 5 배수의 증류수에 오미자를 넣고 Ultrasonic bath $(40 \mathrm{kHz}, 300 \mathrm{~W})$ 에서 $25^{\circ} \mathrm{C}$ 를 유지하며 3시간 추출 후 Whatman(No. 2)여과지로 여과한 뒤 여과액을 $40^{\circ} \mathrm{C}$ 에서 회전감압농축기(IKA RV10, IKA Works Inc., Wilmington, NC, USA)로 농축하여 사용하였다. 쌀가루는 멥쌀을 2 회 수세 후 상온 $\left(20^{\circ} \mathrm{C}\right)$ 에서 8 시간 수침한 다음, 2 시간동안 체에 밭쳐 물 빼기를 한 뒤 분쇄기 (NSG-1002SS)로 분쇄 후 $20 \mathrm{mesh}$ 체에 걸러 사용하였다.

설기떡은 오미자를 첨가하지 않은 백설기를 대조구(C) 로 하였고, 쌀가루 대비 열풍건조 오미자 분말( $\mathrm{DP}$, 수분함 량 $9.12 \% \pm 0.98)$, 동결건조 오미자 분말( $\mathrm{FP}$, 수분함량 $6.25 \% \pm 0.52)$, 열풍건조 오미자 추출물 $(\mathrm{DE}$, 고형분 $76 \%)$, 동결 오미자 추출물 $(\mathrm{FE}$, 고형분 $76 \%)$ 을 $1 \%$ 첨가하였다. 쌀가루 대비 소금 및 설탕은 $1 \%$ 를 첨가하였으며 물은 $10 \%$ 첨가하였다. 가로·세로가 $5 \times 5 \mathrm{~cm}$ 의 stainless steel 시루 안에 시루밑을 깔고 재료를 넣은 후 $4 \mathrm{~cm}$ 두께가 되도록 표면을 고르게 준비하였다. $100^{\circ} \mathrm{C}$ 로 예열된 찜기에서 20 분간 찐 후 5 분간 뜸들인 뒤 30 분간 식혔다. 식힌 설기떡을 nylon/ polyethylene film에 열접합 포장 후 $25^{\circ} \mathrm{C}$ 에 저장하였다. 분 석은 $0,1,3,5$ 일차 간격으로 진행하였다.

\section{수분함량 및 $\mathrm{pH}$ 측정}

오미자 설기떡의 수분측정은 적외선 수분 측정기 (FD-720, Kett Electric Laboratory, Tokyo, Japan)로 측정하 였다. 시료를 각각 $3 \mathrm{~g}$ 씩 곱게 으깨어 은박접시에 얇게 펴서 수분측정기에 넣고 측정하였으며 각 시료는 3 회 반복 측정 하여 그 평균값을 구하였다. $\mathrm{pH}$ 는 시료와 증류수를 1:4로 하여 마쇄한 후 거즈로 여과한 액을 pH meter(Orion $3 \mathrm{star}$, Thermo Electron Co., Beverly, MA, USA)를 사용하여 3회 반복 측정하여 평균값을 사용하였다.

\section{색도 측정}

저장 중 오미자 설기떡의 색도는 표준 백색판 $\left(\mathrm{L}^{*}=97.79\right.$, $\left.\mathrm{a}^{*}=-0.38, \mathrm{~b}^{*}=2.05\right)$ 으로 보정된 Colorimeter(CR-400, Minolta Co., Osaka, Japan)를 사용하였다. 시료를 임의로 선택하여 10 회 반복 측정한 후 평균값을 이용하였으며, $\mathrm{L}^{*}, \mathrm{a}^{*}, \mathrm{~b}^{*}$ 값을 나타내었다.

\section{총 페놀 함량 측정}

총 페놀성 화합물은 Folin-denis법(18)을 응용하여 정량 하였다. 분쇄한 설기떡에 $80 \%$ 메탄올을 첨가 후 Shaking water bath(JSSB-50T, JS Research Inc., Gongju, Chungnam, Korea)에서 $30^{\circ} \mathrm{C}, 120 \mathrm{rpm}$ 으로 3시간 추출하여 여과한 다음 감압농축기(IKA RV10, IKA Works Inc)를 이용하여 농축하 였다. 농축액 $100 \mathrm{mg}$ 을 $80 \%$ 메탄올 $1 \mathrm{~mL}$ 로 녹여 시료로 
사용하였다. 시료용액 $0.2 \mathrm{~mL}$ 와 증류수 $1.8 \mathrm{~mL}$ 를 혼합 한 뒤 Folin-Ciocalteu's regent(Sigma chemical Co., St. Louis, $\mathrm{MO}$, USA) $0.2 \mathrm{~mL}$ 와 혼합하여 10 분간 방치한 후 $10 \%$ $\mathrm{Na}_{2} \mathrm{CO}_{3} 2 \mathrm{~mL}$ 를 가하여 1시간동안 반응시켜 $750 \mathrm{~nm}$ 에서 흡광도를 측정하였으며, gallic acid(Sigma-Aldrich, Steinheim, Germany)를 표준물질로 하여 총 페놀성 화합물의 함량을 나타내었다.

\section{FRAP(ferric reducing antioxidant power) 활성}

FRAP assay는 Benzie와 Strain의 방법(19)을 사용하였다. 반응액은 acetate buffer(pH 3.6, $300 \mathrm{mM}): 10 \mathrm{mM}$ 의 TPTZ (2,4,6-tripyridyl-s-triazine):20 mM의 $\mathrm{FeCl}_{3} \cdot 6 \mathrm{H}_{2} \mathrm{O}$ 를 $10: 1: 1$ 의 비율로 실험 직전에 혼합하여 $35^{\circ} \mathrm{C}$ 에서 10 분간 방치한 뒤, 페놀 함량 측정 시 사용한 동일한 시료용액 $0.2 \mathrm{~mL}$ 와 혼합액 $1.8 \mathrm{~mL}$ 를 30 분간 반응시키고 $590 \mathrm{~nm}$ 에서 흡광도를 측정하였다. 측정한 흡광도는 Trolox(Sigma-Aldrich)를 표 준물질로 하여 $\mu \mathrm{M}$ TE로 나타내었다.

\section{Monomeric anthocyanin 함량}

Monomeric anthocyanin 함량은 $\mathrm{pH}$ differential method (20)를 이용하여 측정하였다. $0.025 \mathrm{M}$ potassium chloride (Daejung chemicals \& metals Co., Shiheung, Gyeonggi, Korea) buffer로 페놀 함량 측정 시 사용한 동일한 시료용액 을 희석하여 흡광도 값이 0.8 1.0이 나오도록 희석배수를 정하고 그 희석배수로 시료용액을 $0.025 \mathrm{M}$ potassium chloride buffer(pH 1.0)와 0.4 M sodium acetate(Duksan pure chemicals Co., Ltd., Ansan, Korea) buffer(pH 4.5)로 각각 희석하였다. 15 분 동안 평형화시킨 후 spectrophotometer (Evolution 201, Thermo Fisher Scientific Inc., Madison, WI, USA)를 사용하여 최대흡수파장 $515 \mathrm{~nm}$ 과 $700 \mathrm{~nm}$ 에서 흡 광도를 측정한 후 다음 식에 의하여 monomeric anthocyanin 함량을 산출하였다(21).

$$
\text { Monomeric anthocyanin }(\mathrm{mg} / \mathrm{L})=\frac{\mathrm{A} \times \mathrm{MW} \times \mathrm{DF} \times 1000}{\varepsilon \times 1}
$$

$\mathrm{A}=\left(\mathrm{A}_{\lambda} \text { vis-max }-\mathrm{A}_{700} \mathrm{~nm}\right)_{\mathrm{pH} 1.0}-\left(\mathrm{A}_{\lambda} \text { vis-max }-\mathrm{A}_{700} \mathrm{~nm}\right)_{\mathrm{pH} 4.5}$

$\mathrm{A}_{\Lambda}$ vis-max : 최대흡수파장에서의 흡광도

$\mathrm{A}_{700 \mathrm{~nm}}$ : $700 \mathrm{~nm}$ 에서의 흡광도

MW : cyanidin-3-glucoside의 분자량 $=449.2$

$\mathrm{DF}$ : 희석배수

$\varepsilon$ : 몰흡광계수 $=26,900$

\section{Schisandrin 함량}

Schisandrin함량은 페놀 함량 측정 시 사용한 동일한 시료 용액을 $0.2 \mu \mathrm{m}$ membrane filter로 여과하여 HPLC(1260 Infinity, Agilent Co., Santa Clara, CA, USA)로 분석하였다.
시료 주입 용량은 $10 \mu \mathrm{L}$ 이고 칼럼은 $\mathrm{C}_{18}$ (Semi-preparative $4.6 \times 150 \mathrm{~mm}, 5 \mu \mathrm{m}$, Agilent), 이동상용매는 Table 1과 같은 gradient를 사용하였다. 유속 $1 \mathrm{~mL} / \mathrm{min}$, 검출기 UV $254 \mathrm{~nm}$ 의 조건으로 분석하였다(22).

\section{통계 분석}

실험결과는 SPSS(Statistical Package for Social Sciences, SPSS Inc., Chicago IL, USA) software package 프로그램 중에서 분산분석(ANOVA)을 실시하여 유의성이 있는 경 우에 Duncan의 다중범위검정(Duncan's multiple range test) 으로 시료간의 유의차를 검증하였다 $(\mathrm{p}<0.05)$.

Table 1. Composition of mobile phases (Multi-Linear Binary Gradient) for schisandrin analysis by HPLC

\begin{tabular}{ccc}
\hline Time (min) & Acetonitrile & Distilled water \\
\hline 0 & 20 & 80 \\
15 & 100 & 0 \\
20 & 20 & 80 \\
\hline
\end{tabular}

\section{결과 및 고찰}

\section{수분함량 및 $\mathrm{pH}$ 의 변화}

오미자를 첨가한 설기떡의 저장 기간 동안 수분함량 변 화는 Table 2에 나타내었다. 열풍건조 오미자 분말 및 동결 건조 오미자 분말 첨가구의 수분함량은 $33.64 \%$ 및 $33.53 \%$ 로 낮은 함량을 나타냈으며, 열풍건조 오미자 추출물 및 동결 오미자 추출물 첨가구의 경우 $34.37 \%$ 및 $34.70 \%$ 로 높은 함량을 나타내었다. 이러한 결과는 동결건조 및 열풍 건조 오미자 분말이 습식 쌀가루보다 낮은 수분함량을 나타 내어, 분말 첨가량을 증가시킬수록 설기떡 표면의 수분이

Table 2. Changes in moisture contents of steamed rice cake added with powder and extract of schisandra chinensis during storage for 5 days at $25^{\circ} \mathrm{C}$

\begin{tabular}{ccccc}
\hline Sample $^{1}$ & \multicolumn{4}{c}{ Storage period (day) } \\
\cline { 2 - 5 } & 0 & 1 & 3 & 5 \\
\hline C & $34.09 \pm 0.54^{\mathrm{a} 2) \mathrm{BC} 3)}$ & $33.90 \pm 0.43^{\mathrm{abAB}}$ & $33.93 \pm 0.34^{\mathrm{abAB}}$ & $33.67 \pm 0.15^{\mathrm{bAB}}$ \\
DP & $33.64 \pm 0.62^{\mathrm{aAB}}$ & $33.39 \pm 0.75^{\mathrm{aA}}$ & $33.18 \pm 1.00^{\mathrm{aA}}$ & $33.24 \pm 0.52^{\mathrm{aA}}$ \\
FP & $33.53 \pm 0.42^{\mathrm{aA}}$ & $33.56 \pm 0.74^{\mathrm{aA}}$ & $33.26 \pm 0.37^{\mathrm{aA}}$ & $33.22 \pm 0.67^{\mathrm{aA}}$ \\
DE & $34.37 \pm 0.42^{\mathrm{aCD}}$ & $34.22 \pm 0.21^{\mathrm{aB}}$ & $34.03 \pm 0.78^{\mathrm{aAB}}$ & $34.07 \pm 0.40^{\mathrm{aB}}$ \\
FE & $34.70 \pm 0.21^{\mathrm{aD}}$ & $34.48 \pm 0.31^{\mathrm{aB}}$ & $34.52 \pm 0.77^{\mathrm{aB}}$ & $34.10 \pm 0.87^{\mathrm{aB}^{3}}$ \\
\hline
\end{tabular}

${ }^{1)} \mathrm{C}$, Control; DP, Hot-air dried Schisandra chinensis was added as powder; FP, Freeze dried Schisandra chinensis was added as powder; DE, Hot-air dried Schisandra chinensis was added as a concentrate; FE, Frozen Schisandra chinensis was added as a concentrate. ${ }^{2) a-e}$ Means in the same row preceded by different superscripts are significantly different $(\mathrm{p}<0.05)$ by Duncan's multiple range test.

${ }^{3) \mathrm{A}-\mathrm{E}}$ Means in the same column followed by different superscripts are significantly different $(p<0.05)$ by Duncan's multiple range test. 
손실을 받기 때문이라고 연구한 결과와 유사하였다(23). 저장기간에 따른 수분함량은 대조구를 제외한 모든 구에서 유의적인 차이를 나타내지 않았다. 이러한 결과는 연잎가 루(24) 및 백봉령가루(25)를 첨가한 설기떡의 경우 저장기 간 중 수분함량의 변화에 유의적인 차이가 나타나지 않았다 고 보고한 결과와 일치하였다.

오미자를 첨가한 설기떡의 저장 기간 동안 $\mathrm{pH}$ 변화는 Table 3에 나타내었다. 대조구의 경우 6.43으로 가장 높았으 며 동결 오미자 추출물 첨가구가 4.19로 가장 낮은 것으로 나타났다. 대조구의 경우 저장기간이 길어질수록 $\mathrm{pH}$ 가 감 소하여 5 일차에 6.00 을 나타내었다. 이는 미생물이 증식함 에 따라 발생한 산에 의한 것으로 사료된다. 오미자 설기떡 은 대조구에 비해 낮은 $\mathrm{pH}$ 를 나타내었는데, 이는 오미자에 함유된 citric acid, malic acid, succinic acid 등 높은 유기산 함량(26)에 기인한 것으로 판단되며, 오미자 첨가구에 따른 차이는 추출물 첨가구가 분말 첨가구 보다 낮은 $\mathrm{pH}$ 를 나타 내었다. 저장기간에 따른 $\mathrm{pH}$ 값은 대조구를 제외한 모든 구에서 유의적인 차이를 나타내지 않았다.

Table 3. Changes in $\mathrm{pH}$ of steamed rice cake added with powder and extract of schisandra chinensis during storage for 5 days at $25^{\circ} \mathrm{C}$

\begin{tabular}{ccccc}
\hline \multirow{2}{*}{ Sample $^{1)}$} & \multicolumn{4}{c}{ Storage period (day) } \\
\cline { 2 - 5 } & 0 & 1 & 3 & 5 \\
\hline C & $6.43 \pm 0.00^{\mathrm{a} 2 \mathrm{~A} \mathrm{~A} 3)}$ & $6.25 \pm 0.01^{\mathrm{bA}}$ & $6.23 \pm 0.02^{\mathrm{bA}}$ & $6.00 \pm 0.01^{\mathrm{cA}}$ \\
DP & $4.63 \pm 0.01^{\mathrm{aB}}$ & $4.59 \pm 0.01^{\mathrm{aB}}$ & $4.60 \pm 0.04^{\mathrm{aB}}$ & $4.57 \pm 0.02^{\mathrm{aB}}$ \\
FP & $4.55 \pm 0.01^{\mathrm{aC}}$ & $4.51 \pm 0.02^{\mathrm{bC}}$ & $4.52 \pm 0.01^{\mathrm{bC}}$ & $4.50 \pm 0.01^{\mathrm{bC}}$ \\
DE & $4.20 \pm 0.03^{\mathrm{aD}}$ & $4.23 \pm 0.02^{\mathrm{aD}}$ & $4.23 \pm 0.00^{\mathrm{aD}}$ & $4.20 \pm 0.01^{\mathrm{aD}}$ \\
FE & $4.19 \pm 0.01^{\mathrm{aD}}$ & $4.17 \pm 0.01^{\mathrm{aE}}$ & $4.18 \pm 0.01^{\mathrm{DD}}$ & $4.17 \pm 0.01^{\mathrm{aE}}$ \\
\hline
\end{tabular}

${ }^{1)}$ C, Control; DP, Hot-air dried Schisandra chinensis was added as powder; FP, Freeze dried Schisandra chinensis was added as powder; DE, Hot-air dried Schisandra chinensis was added as a concentrate; FE, Frozen Schisandra chinensis was added as a concentrate. ${ }^{2 / a-e}$ Means in the same row preceded by different superscripts are significantly different $(p<0.05)$ by Duncan's multiple range test.

${ }^{3) A-E}$ Means in the same column followed by different superscripts are significantly different $(\mathrm{p}<0.05)$ by Duncan's multiple range test.

\section{색도의 변화}

오미자를 첨가한 설기떡의 색도 변화는 Fig. 1에 나타내 었다. 명도(lightness, L)값은 대조구의 경우 82.02 로 가장 높았으며, 열풍건조 오미자 분말 첨가구가 73.31로 높은 값을 나타내었다. 동결건조 오미자 분말 및 추출물 첨가구 는 유의적인 차이 없이 가장 낮은 값을 나타내었다. 저장 기간 중 대조구의 값은 유의적인 차이 $(\mathrm{p}<0.05)$ 를 나타내며 낮아졌다. 열풍 및 동결건조 분말 오미자 첨가구의 경우 3 일차부터 유의적인 차이 $(\mathrm{p}<0.05)$ 를 나타내며 낮아졌으며, 추출물 첨가구의 경우 저장기간 중 유의적인 차이는 나타나 지 않았다. 적색도(redness, $\mathrm{a}^{*}$ )값의 경우 대조구의 값이 -1.65 로 가장 낮았다. 열풍건조 분말 및 추출물 첨가구의
경우 4.95 및 4.07로 낮은 반면, 동결건조 분말 및 동결 오미자 추출물 첨가구의 경우 10.97 및 6.61로 높은 값을 나타내었다. 이러한 차이는 열풍건조 오미자 보다 동결건 조 오미자의 안토시아닌 함량(Fig. 4)이 상대적으로 높기 때문인 것으로 판단된다. 저장 기간 중 대조구는 유의적인 차이 $(\mathrm{p}<0.05)$ 를 나타내며 증가하는 반면, 대조구를 제외한 첨가구들은 큰 차이를 나타내지 않았다. 황색도(yellowness, $\mathrm{b}^{*}$ )값의 경우 열풍건조 분말 및 추출물 첨가구는 8.61 및 10.99 로 높았으며, 동결건조 오미자 분말 및 동결 오미자 추출물 첨가구는 5.07 및 7.53으로 낮았다. 이는 열풍건조 오미자의 색상이 붉은색 보다는 황색을 나타내어 $\mathrm{b}^{*}$ value 의 값이 증가한 것으로 판단된다.

\section{총 페놀 함량의 변화}

오미자를 첨가한 설기떡의 총 페놀 함량의 변화는 Fig. 2에 나타내었다. 대조구의 경우 $3.00 \mathrm{mg} / 100 \mathrm{~g}$ 로 가장 낮은 값을 나타냈으며, 열풍건조 분말 및 추출물 함량이 4.89 및 $5.19 \mathrm{mg} / 100 \mathrm{~g}$ 로 나타났다. 동결건조 오미자 분말 및 동결 오미자 추출물의 경우 5.86 및 $6.99 \mathrm{mg} / 100 \mathrm{~g}$ 로 높은 값을 나타냈다. 저장 기간이 길어질수록 감소하는 경향을 나타내었다. 건조방법을 달리한 오미자의 품질특성 및 항 산화 효과(27)에 의해 보고된 총 페놀 함량에 따르면, 동결 건조 오미자가 열풍건조 오미자 보다 높은 페놀함량을 나타 낸 것과 유사하였다. 열풍 건조 오미자의 경우 열에 의하여 유용성분의 유출에 따른 손실이 일어난 것으로 판단되며, 오미자를 사용하여 총 페놀 함량이 높은 설기떡을 가공하기 위해선 동결 오미자를 첨가해야 할 것으로 판단된다.

\section{$\mathrm{FRAP}$ 활성의 변화}

오미자를 첨가한 설기떡의 FRAP 활성 변화는 Fig. 3에 나타내었다. FRAP assay는 항산화물질이 3 가철을 2 가철로 환원시킬 때에 2 가철이 나타내는 흡광도를 측정함으로써 항산화능을 측정하는 방법이다(19). 대조구의 경우 제조 직후 $467.55 \mu \mathrm{M}$ TE로 가장 낮은 값을 나타냈으며, 5 일차에 $402.25 \mu \mathrm{M} \mathrm{TE}$ 로 저장기간이 길어질수록 유의적 $(\mathrm{p}<0.05)$ 으 로 감소하였다. 열풍건조 분말 및 추출물 첨가 설기떡이 655.33 및 $745.14 \mu \mathrm{M} \mathrm{TE}$ 로 동결건조 오미자 분말 및 동결 오미자 추출물 첨가구의 787.23 및 $910.65 \mu \mathrm{M} \mathrm{TE}$ 보다 낮은 값을 나타내었다. 저장기간 동안 유의적( $\mathrm{p}<0.05)$ 으로 감소 하였으며, 5 일차 동결 오미자 추출물 설기떡이 $709.93 \mu \mathrm{M}$ $\mathrm{TE}$ 로 가장 높은 값을 나타내었다. 따라서, 오미자를 사용하 여 항산화 활성이 높은 설기떡을 가공하기 위해선 동결 오미자를 첨가해야 할 것으로 판단된다.

\section{Monomeric anthocyanin 함량의 변화}

오미자를 첨가한 설기떡의 안토시아닌 함량의 변화는 Fig. 4에 나타내었다. 대조구에서는 안토시아닌이 검출되 

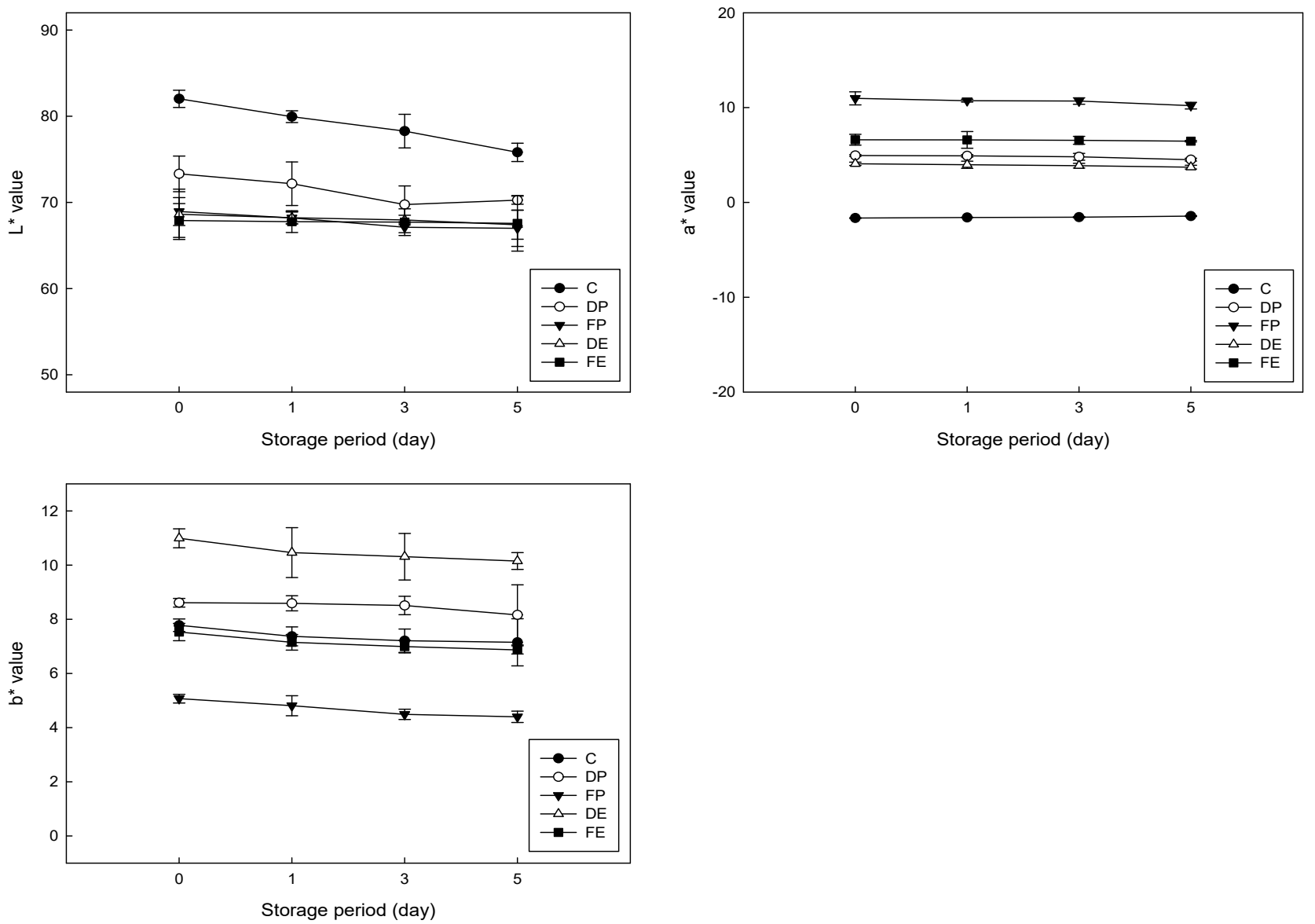

Fig. 1. Changes in color values of steamed rice cake added with powder and extract of schisandra chinensis during storage for 5 days at $25^{\circ} \mathrm{C}$.

C, Control; DP, Hot-air dried Schisandra chinensis was added as powder; FP, Freeze dried Schisandra chinensis was added as powder; DE, Hot-air dried Schisandra chinensis was added as a concentrate; FE, Frozen Schisandra chinensis was added as a concentrate. Dots and vertical bars represent the means \pm SD.

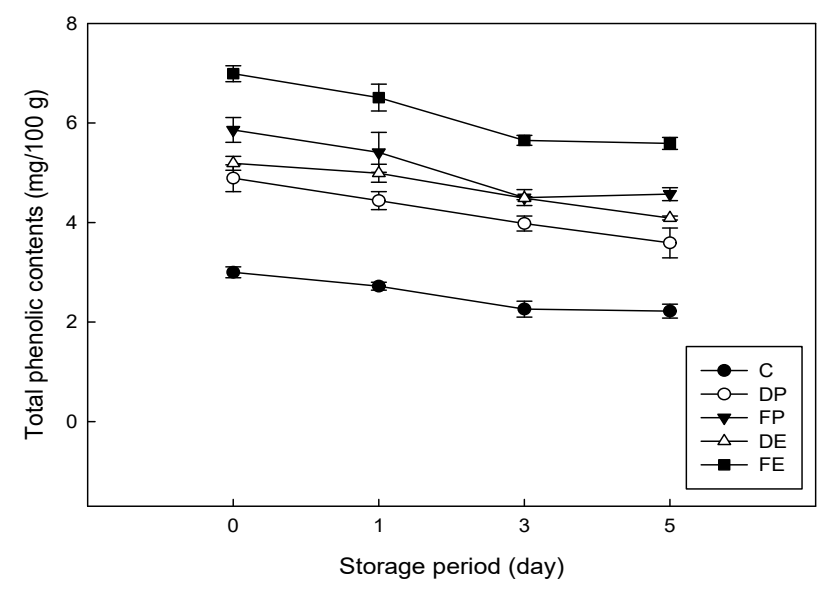

Fig. 2. Changes in total phenolic contents of steamed rice cake added with powder and extract of schisandra chinensis during storage for 5 days at $25^{\circ} \mathrm{C}$.

C, Control; DP, Hot-air dried Schisandra chinensis was added as powder; FP, Freeze dried Schisandra chinensis was added as powder; DE, Hot-air dried Schisandra chinensis was added as a concentrate; FE, Frozen Schisandra chinensis was added as a concentrate. Dots and vertical bars represent the means \pm SD.

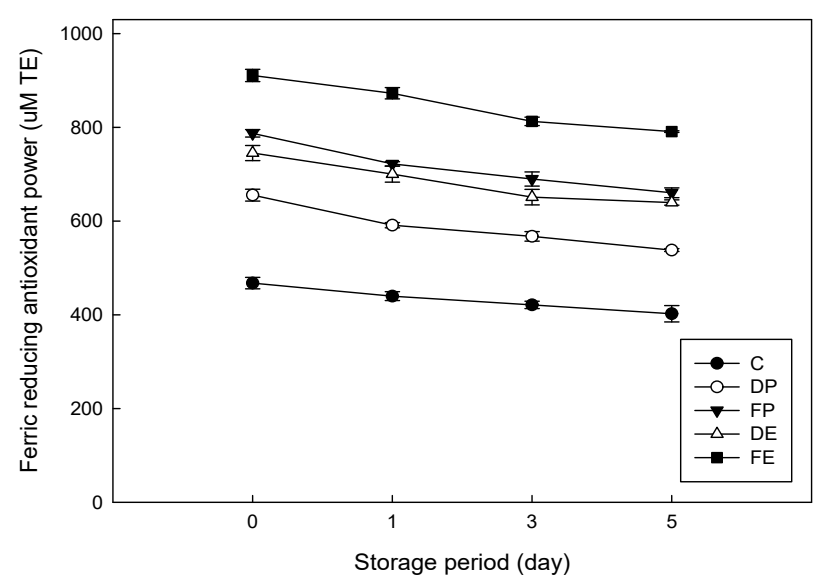

Fig. 3. Changes in ferric reducing antioxidant power (FRAP) of steamed rice cake added with powder and extract of schisandra Chinensis during storage for 5 days at $25^{\circ} \mathrm{C}$.

C, Control; DP, Hot-air dried Schisandra chinensis was added as powder; FP, Freeze dried Schisandra chinensis was added as powder; DE, Hot-air dried Schisandra chinensis was added as a concentrate; FE, Frozen Schisandra chinensis was added as a concentrate. Dots and vertical bars represent the means \pm SD. 


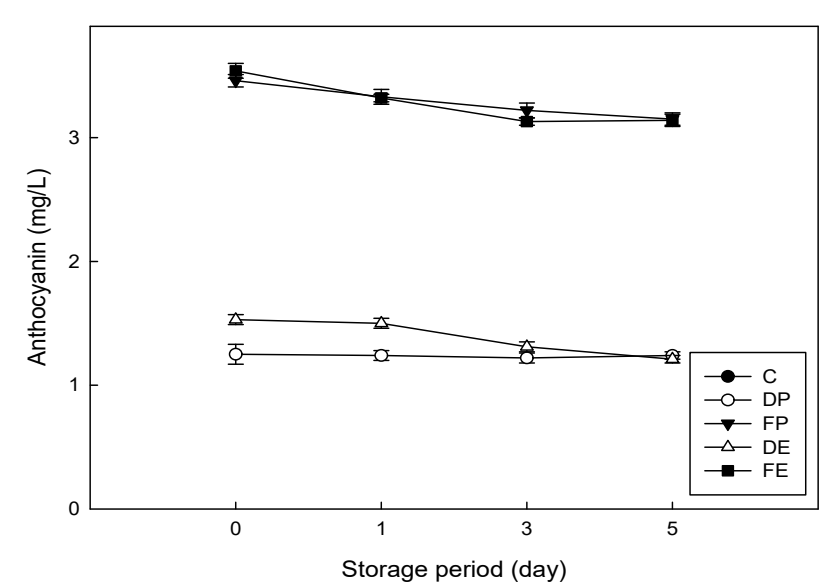

Fig. 4. Changes in anthocyanin contents of steamed rice cake added with powder and extract of schisandra Chinensis during storage for 5 days at $25^{\circ} \mathrm{C}$.

C, Control; DP, Hot-air dried Schisandra chinensis was added as powder; FP, Freeze dried Schisandra chinensis was added as powder; DE, Hot-air dried Schisandra chinensis was added as a concentrate; FE, Frozen Schisandra chinensis was added as a concentrate. Dots and vertical bars represent the means $\pm S D$.

지 않았다. 이는 여러 가지 특수미의 일부 항산화 성분 분석 (28) 연구에서 일반미에서 안토시아닌이 검출되지 않았다 는 연구와 일치하였다. 열풍건조 분말 및 추출물 첨가구의 안토시아닌 함량은 1.25 및 $1.53 \mathrm{mg} / \mathrm{L}$ 로 동결건조 오미자 분말 및 동결 오미자 추출물 첨가구의 함량 3.46 및 3.54 $\mathrm{mg} / \mathrm{L}$ 보다 낮은 것으로 확인되었다. 동결건조 오미자 분말 및 추출물 첨가구는 저장기간 동안 유의적 $(\mathrm{p}<0.05)$ 으로 감 소하여 3.15 및 $3.14 \mathrm{mg} / \mathrm{L}$ 를 나타내었으며, 열풍 건조 오미 자 분말 및 추출물 첨가구는 1.24 및 $1.21 \mathrm{mg} / \mathrm{L}$ 를 나타내었 다. 안토시아닌의 열안정성에 대한 연구(29)에 의해 보고된 안토시아닌 함량의 경우 열의 온도가 올라갈수록, 열의 지 속 시간이 길어질수록 안토시아닌 함량이 줄어든다고 보고 된 결과와 유사하다. 또한 건조 오미자의 저장기간이 길어 질수록 안토시아닌의 함량이 줄어든다는 보고(9)에 따라, 가공 전 열풍건조 오미자의 저장기간 또한 변수요인이 될 수 있는 것으로 사료된다.

\section{schisandrin 함량의 변화}

오미자를 첨가한 설기떡의 schisandrin함량의 변화는 Fig. 5에 나타내었다. 대조구에는 schisandrin이 존재하지 않는 것으로 확인 되었다. 열풍건조 및 동결건조 오미자 분말 첨가구의 함량은 1.28 및 $1.41 \mathrm{mg} / \mathrm{L}$ 로 낮게 나타났으 며, 열풍건조 오미자 추출물 및 동결 오미자 추출물의 함량 은 7.03 및 $9.86 \mathrm{mg} / \mathrm{L}$ 로 높게 나타났다. 저장 중 함량의 변화는 큰 차이가 없었다. 가공된 오미자 설기떡의 schisandrin 함량은 열풍건조 및 동결 오미자의 차이보단 추출방법에 영향을 받는 것으로 나타났다. Choi 등(30)의 연구에 따르 면, 오미자에 포함된 30여종이 넘는 lignan성분 중 schisandrin의 함량이 가장 높은 것으로 보고되으며, 과실보
단 종자에 약 9배 많이 포함되어 있다. 따라서 오미자를 사용하여 schisandrin함량이 높은 설기떡을 가공하기 위해 선 오미자 분말을 첨가하는 것보다 추출물을 첨가하는 것이 효과적인 것으로 판단된다.

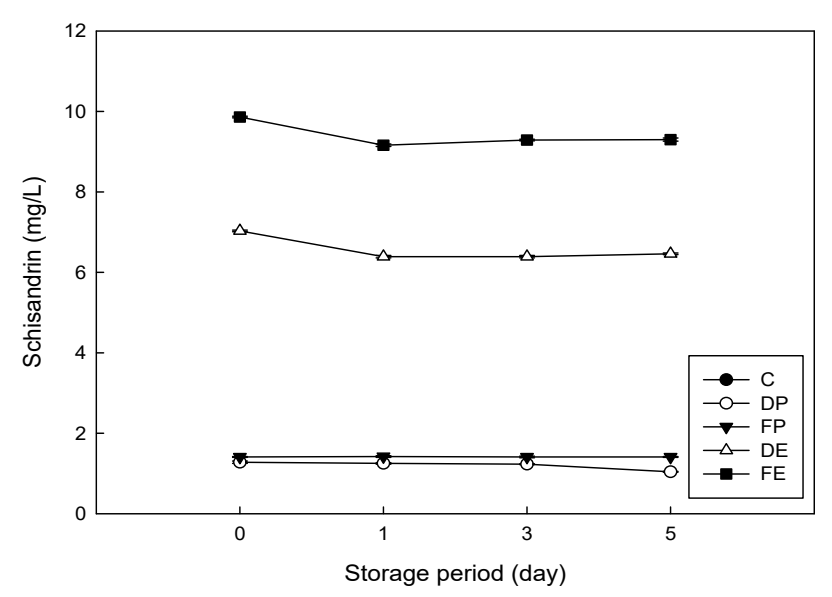

Fig. 5. Changes in schisandrin contents of steamed rice cake added with powder and extract of schisandra chinensis during storage for 5 days at $25^{\circ} \mathrm{C}$.

C, Control; DP, Hot-air dried Schisandra chinensis was added as powder; FP, Freeze dried Schisandra chinensis was added as powder; DE, Hot-air dried Schisandra chinensis was added as a concentrate; FE, Frozen Schisandra chinensis was added as a concentrate. Dots and vertical bars represent the means \pm SD.

\section{요 약}

열풍건조 오미자 분말(DP), 열풍건조 오미자 추출물 $(\mathrm{DE})$, 동결건조 오미자 분말 $(\mathrm{FP})$, 동결 오미자 추출물 $(\mathrm{FE})$ 을 각각 $1 \%$ 첨가한 설기떡을 $25^{\circ} \mathrm{C}$ 에서 5 일간 저장하며 이화학적 특성, 기능성 성분 및 항산화 활성을 연구하였다. $\mathrm{pH}$ 는 동결 오미자 추출물 첨가 설기떡이 4.19로 낮은 값을 나타냈으며, 대조구는 6.43으로 높은 값을 나타내었다. 대 조구는 저장기간 중 낮아지는 경향을 나타냈으나, 오미자 분말 및 추출물 첨가구는 유의적 차이가 없었다. $\mathrm{L}^{*}$ value는 가공 직후 대조구의 값이 가장 높았으나, 저장기간 중 감소 하였다. $\mathrm{a}^{*}$ value는 동결건조 오미자 첨가구가 열풍건조 오 미자 첨가구보다 높은 값을 나타내었으며, $\mathrm{b}^{*}$ value는 열풍 건조 오미자 첨가구가 동결 오미자 첨가구 보다 높은 값을 나타내었다. 총 페놀 함량 및 FRAP 활성은 동결 오미자 첨가구가 열풍건조 오미자 첨가구 보다 높은 함량을 나타내 었다. Anthocyanin 및 schisandrin은 대조구에서 검출되지 않았다. 안토시아닌 함량은 열풍건조 오미자 첨가구 보다 동결 오미자 첨가구에서 높은 함량을 나타내었다. Schisandrin 함량은 오미자 분말 첨가구보다 오미자 추출물 첨가구에서 높은 함량을 나타내었다. 이상의 결과를 토대 로 기능성 성분 및 항산화능을 고려하여 볼 때 동결 오미자 추출물을 설기떡에 첨가하면 우수한 설기떡을 제조할 수 
있을 것으로 판단된다.

\section{감사의 글}

이 연구는 2015년 경북대학교 복현학술연구비의 지원을 받아 이루어 졌으며 이에 감사드립니다.

\section{References}

1. Yoon MH, Kim KH, Hwang HR, Jo JE, Kim MS, Yook HS (2009) Quality characteristics and antioxidant activity of chocolate containing flowering cherry (Prunus serrulata L. var. spontanea Max. wis.) fruit powder. J Korean Soc Food Sci Nutr, 38, 1600-1605

2. Jang EH, Pyo YH, Ahn MS (1996) Antioxidant effect of Omija (Schizandra Chinesis Baillon) extracts. Korean J Soc Food Sci, 12, 372-376

3. Kim KS, Kang SS, Ryu SN (2002) Quantitative analysis of lignans from fruits of schizandra chinensis. Kor J Pharmacogn, 33, 272-276

4. Kim JS, Choi SY (2008) Physicochemical properties and antioxidative activities of Omija (Schizandra Chinensis Baillon). J Korean Soc Food Sci Nutr, 21, 35-42

5. Chung KH, Lee SH, Lee YC, Kim JT (2001) Antimicrobial activity of Omija (Schizandra chinensis) extracts. J Korean Soc Food Sci Nutr, 30, 127-132

6. Rho SN, Oh HS (2002) Effect of Omija (Schizandra Chinensis Baillon) extracts on the growth of liver cancer cell line SNU-398. Korean J Nutr, 35, 201-206

7. Chae HJ, Lee IS, Moon HY (2011) Effects of schizandra chinensis fruit extract on the hyperglycemia and hyperlipemia in streptozotocin-induced diabetic rats. Korean Soc Biotechnol Bioeng J, 26, 126-130

8. Cho EK, Cho HE, Choi YJ (2010) Inhibitory effects of angiotensin converting enzyme and a-Glucosidase, and alcohol metabolizing activity of fermented Omija (Schizandra Chinensis Baillon) beverage. J Korean Soc Food Sci Nutr, 39, 665-661

9. Choi YH, Cheong YK, Park KH, Park MS (2001) Changes of quality in dried Omija (Schizandra Chinensis Baillon) during storage. Korean J Postharvest Sci Technol, 8, 351-355

10. Kwon HJ, Park CS (2011) Development and quality characteristics of bellflower root Jeonggwa added Omija (Schizandra Chinensis Baillon) during storage. Korean
J Food Preserv, 18, 279-287

11. Park LY, Lee SH, Kim SJ (2010) Preparation and sensory characteristics of bread containing Schizandra chinensis Baillon (a traditional Korean medicinal plant). Korean J Food Preserv, 17, 637-643

12. Kim JS, Choi SY (2008) Quality characteristics of soybean curd with Omija extract. Korean J Food Nutr, 21, 43-50

13. Son SM (2001) Rice based meal for prevention of obesity and chronic disease. Korean J Community Nutr, 6, 862-867

14. Hyun YH, Hwang YK, Lee YS (2005) Quality characteristics of Sulgidduk with tapioca flour. Korean J Food Nutr, 18, 103-108

15. Joo SY (2013) Antioxidant activity and quality characteristics of Sulgidduk prepared with Prunus yedoensis matsumura extract. Korean J Food Cookery Sci, 29, 115-122

16. Shin JH, Kim YA, Kang MJ, Yang SM, Sung NJ (2010) Preparation and characteristics of sulgidduk containing different amounts of black garlic extract. Korean J Food Cookery Sci, 26, 559-566

17. Yoo SS, Ko SH (2014) Quality characteristics of Sulgidduk with beet leaf powder. Korean J Food Cookery Sci, 30, 119-128

18. Singleton VL, Rossi JA (1965) Colorimetry of total phenolics with phosphomolybdic-phosphotungstic acid reagents. Am J Enol Vitic, 16, 144-158

19. Benzie IFF, Strain JJ (1996) The ferric reducing ability of plasma (FRAP) as a measure of antioxidant power : The FRAP assay. Anal Biochem, 239, 70-76

20. Giusti MM, Wrolstad RE (2001) Characterization and measurement of anthocyanins by UV-visible spectroscopy. In Current procotols in Food analytical Chemistry, Wrolstad RE (Editor), John Wiley and Sons, New York, USA

21. Lee BK, Shin HH, Jung JH, Hwang KT, Lee YS, Kim TY (2009) Anthocyanins, polyphenols and antioxidant activities of black raspberry exudates. J Korean Soc Food Sci Nutr, 38, 125-130

22. Koo DC, Suh WS, Baek SY, Shim SH (2011) Quantitative determination of lignans from schizandra chinensis by HPLC. Kor J Pharmacogn, 42, 233-239

23. Ahn GJ (2010) Quality characteristics of Sulgidduk added by different amount of bamboo leaf flour. Korean J Cul Res, 16, 104-111

24. Yoon SJ (2007) Quality characteristics of Sulgitteok 
added with lotus leaf powder. Korean J Food Cookery Sci, 23, 433-442

25. Kim BW, Yoon SJ, Jang MS (2005) Effects of addition baekbokryung (White Poria cocos Wolf) powder on the quality characteristics of Sulgidduk Korean J Food Cookery Sci, 21, 895-907

26. Hyun KH, Kim HJ, Jeong HC (2002) A study on determining chemical compositions of Schizandra Chinensis. Korean J Plant Res, 15, 1-7

27. Lee S, Moon HK, Lee SW, Moon JN, Kim JK (2014) Effects of drying methods on quality characteristics and antioxidative effects of Omija (Schizandra chinesis Bailon). Korean J Food Preserv, 21, 341-349
28. Seo SJ, Choi YM, Lee SM, Kim KJ, Son JR, Lee JS (2007) Determination of selected antioxidant compounds in specialty rice. J Korean Soc Food Sci Nutr, 36, 499-502

29. Bakowska A, Kucharska AZ, Oszmianski J (2003) The effect of heating, UV irradiation and storage on stability of the anthocyanin-polyphenol copigment complex. Food Chem, 81, 349-355

30. Choi SR, Kim CS, Kim JY, You DH, Kim JM, Kim YS, Song EJ, Kim YG, Ahn YS, Choi DG (2011) Changes of antioxidant activity and lignan contents in Schisandra chinensis by harvesting times. Korean J Medicinal Crop Sci, 19, 414-420 